\title{
STABILITAS MARSHALL DAN KETAHANAN DEFORMASI WARM MIX ASPHALT MENGGUNAKAN ADITIF ZYCOTHERM
}

\author{
I Gusti Ngurah Widyantara', Latif Budi Suparma², Imam Muthohar ${ }^{3}$ \\ ${ }_{1}^{1}$ Magister Sistem dan Teknik Transportasi; ${ }^{2,3}$ Departemen Teknik Sipil dan Lingkungan UGM \\ Email: ngurahlobar@gmail.com
}

\begin{abstract}
Warm Mix Asphalt (WMA) is produced at mixing temperatures between $20^{\circ} \mathrm{C}-40^{\circ} \mathrm{C}$ lower than Hot Mix Asphalt (HMA). Zycotherm added ingredients is one of the additives used in Warm Mix Asphalt. This study aims to assess Marshall stability and resistance to deformation by using asphalt type AC 60/70 ex Shell and Zycotherm additives on warm asphalt mixtures. In this study, the test was carried out on a layer of (AC-WC) to four mixed variations ie HMA-0, WMA-1, WMA-2, WMA-3 with 0\% Zycotherm content; 0.10\%; 0.15\% and 0.20\%. Mixed performance is measured by Marshall and Wheel Tracking Machine (WTM) testing. Based on the result of Gyropac test, with Workability Index (WI) value approach, the mixing temperature and compaction of WMA-1, WMA-2 and WMA-3 mixture are respectively obtained temperature $130 / 120^{\circ} \mathrm{C}, 130 / 120^{\circ} \mathrm{C}$ and $140 / 130^{\circ} \mathrm{C}$. The Marshall test, the stability value of all mixtures fulfilled the minimum specification requirement of $800 \mathrm{~kg}$, with the greatest stability value obtained from WMA-1 mixture of $1325 \mathrm{~kg}$ with additive content of $0.10 \%$. The results of the Wheel Tracking Machine (WTM) test, a mixture that has resistance to deformation is a mixture of WMA-1 has the smallest deformation value of $1.93 \mathrm{~mm}$, the largest dynamic stability of 1400 traje / $\mathrm{mm}$ and the smallest deformation velocity of $0.030 \mathrm{~mm} / \mathrm{min}$. That the use of Zycotherm is suitable for use in AC-WC warm mixture, with the optimum value of Zycotherm 0,10\%. The use of excessive Zycotherm content results in a poor AC-WC warm mixture performance.
\end{abstract}

Keywords: Dynamic Stability, Marshall, Warm Mix, Wheel Tracking Machine, Zycotherm.

\begin{abstract}
ABSTRAK
Warm Mix Asphalt (WMA) diproduksi pada suhu pencampuran antara $20^{\circ} \mathrm{C}-40^{\circ} \mathrm{C}$ lebih rendah daripada $\mathrm{Hot}$ Mix Asphalt (HMA). Bahan tambah Zycotherm merupakan salah satu aditif yang digunakan dalam Warm Mix Asphalt. Kajian ini bertujuan untuk mengkaji stabilitas Marshall dan ketahanan terhadap deformasi dengan menggunakan bahan perekat aspal jenis AC 60/70 ex Shell dan aditif Zycotherm pada campuran aspal hangat. Pada kajian ini, pengujian dilakukan pada lapis aus (AC-WC) terhadap empat variasi campuran yaitu HMA-0, WMA-1, WMA-2, WMA-3 dengan kadar Zycotherm 0\%; 0,10\%; 0,15\% dan 0,20\%. Kinerja campuran diukur berdasarkan pengujian Marshall dan Wheel Tracking Machine (WTM). Berdasarkan hasil pengujian Gyropac, dengan pendekatan nilai Workability Index (WI) diperoleh suhu pencampuran dan pemadatan campuran WMA-1, WMA-2 dan WMA-3 secara berurutan diperoleh suhu $130 / 120^{\circ} \mathrm{C}, 130 / 120^{\circ} \mathrm{C}$ dan $140 / 130^{\circ} \mathrm{C}$. Pengujian Marshall diperoleh nilai stabilitas semua campuran memenuhi ketentuan spesifikasi yaitu minimum $800 \mathrm{~kg}$, dengan nilai stabilitas terbesar diperoleh dari campuran WMA-1 sebesar $1325 \mathrm{~kg}$ dengan kadar aditif $0,10 \%$. Hasil pengujian Wheel Tracking Machine (WTM), campuran yang memiliki ketahanan terhadap deformasi adalah campuran WMA-1 memiliki nilai deformasi yang paling kecil sebesar $1,93 \mathrm{~mm}$, stabilitas dinamis terbesar sebesar 1400 lintasan $/ \mathrm{mm}$ dan kecepatan deformasi terkecil sebesar $0,030 \mathrm{~mm} / \mathrm{menit}$. Bahwa penggunaan Zycotherm cocok digunakan pada campuran hangat AC-WC, dengan nilai optimum penggunaan Zycotherm sebanyak $0,10 \%$. Penggunaan kadar Zycotherm yang berlebihan menghasilkan performa campuran hangat AC-WC yang kurang baik.
\end{abstract}

Kata kunci: Stabilitas Dinamis, Marshall, Warm Mix, Whell Tracking Machine, Zycotherm.

\section{PENDAHULUAN}

Meningkatnya beban lalulintas dan iklim tropis di Indonesia memberikan sumbangan kerusakan yang sangat cepat pada perkerasan jalan di Indonesia. Salah satu penyebab utama dan memburuknya kemampuan layan adalah rendahnya daya tahan lapisan perkerasan dalam menerima beban lalu lintas yang sering dihubungkan dengan ketahanan terhadap deformasi permanen (rutting), oleh karena itu diperlukan campuran perkerasan yang bersifat fleksibel dengan stabilitas dan durabilitas tinggi, tidak peka terhadap cuaca panas, tahan oksidasi, tahan 
terhadap rembesan air hujan, dan aman bagi lingkungan. Campuran beraspal panas merupakan campuran beraspal yang memerlukan pemanasan pada temperatur yang cukup tinggi. Salah satu upaya untuk menekan penggunaan bahan bakar dan emisi buang ialah dengan membuat campuran beraspal yang temperatur pencampurannya lebih rendah dari yang umum saat ini, yang dikenal dengan campuran beraspal hangat (warm mix). Warm Mix Asphalt (WMA) adalah salah satu teknologi yang berbasis green construction, dimana campuran aspal hangat diproduksi dengan tingkat penurunan suhu sekitar $20^{\circ}-40^{\circ} \mathrm{C}$ lebih rendah dari campuran aspal panas (Hot Mix Asphalt) secara otomatis akan ada penurunan terhadap jumlah bahan bakar yang digunakan dan penurunan energi yang digunakan. Berbagai macam teknologi yang dapat menurunkan suhu pada campuran aspal hangat yaitu dengan penggunaan aditif organik, bahan kimia tambahan, dan teknologi berbasis busa / foaming (European Asphalt Pavement Association, 2014).

Deformasi permanen pada campuran aspal adalah suatu kerusakan yang terjadi pada suhu perkerasan tinggi setelah terjadinya pembebanan. Seiring dengan meningkatnya suhu perkerasan, campuran aspal menjadi lebih lunak dan lebih rentan. Deformasi permanen terjadi ketika campuran aspal mengalami perubahan bentuk ketika dibebani dan kemudian tidak pulih kembali ke posisi semula (unrecoverable). Seiring waktu, deformasi permanen dapat menyebabkan rutting. (Asphalt Institute, 2014).

Stabilitas dinamis adalah kemampuan dari campuran menahan deformasi atau deformasi akibat beban dinamis dalam suhu tinggi dan parameter uji stabilitas dinamis adalah kedalaman rutting, yang dinyatakan dalam lintasan $/ \mathrm{mm}$. Menurut Direktorat Jenderal Bina Marga (2017) dalam Manual Perkerasan Jalan, membatasi rutting di jalan raya dapat dijelaskan dalam tiga tingkatan: 1. Kerusakan rendah (low severity), kedalaman $<25 \mathrm{~mm}$; 2. Kerusakan sedang (medium severity) yaitu alur kedalaman 25$75 \mathrm{~mm}$, dan; 3. Kerusakan tinggi (high severity) yaitu alur kedalaman $>75 \mathrm{~mm}$, lebih jelas dapat dilihat pada Gambar 1.

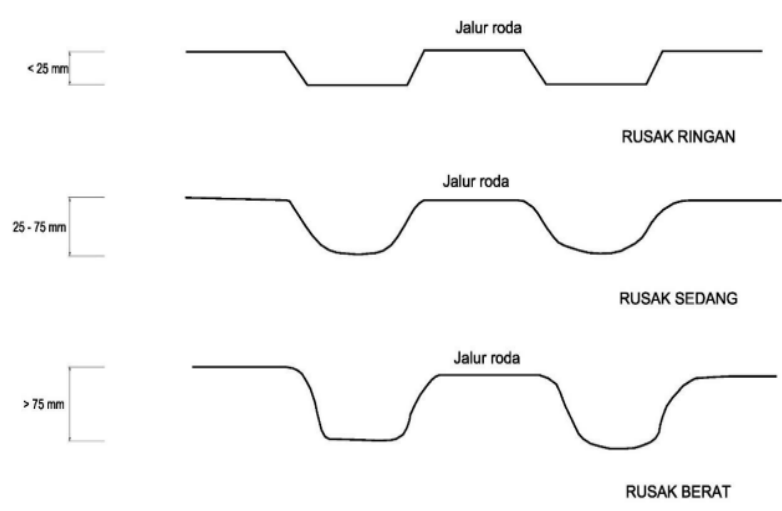

Gambar 1. Tingkat Kerusakan Alur

(Sumber : Manual Perkerasan Jalan, 2017)

Untuk menangani tingkat low severity biasanya penanganan dapat dilakukan dengan overlay, medium severity penanganan dengan menambal sedangkan high severity membutuhkan penanganan berat atau rekonstruksi. kondisi kritis trotoar biasanya terjadi pada suhu di atas $50^{\circ} \mathrm{C}$ atau di bawah suhu $5^{\circ} \mathrm{C}$. Pada suhu tinggi, perkerasan aspal akan rentan terhadap deformasi plastik yang disebabkan oleh beban lalulintas. Hubungan Marshall Stability dan Dynamic Stability adalah sama baiknya untuk menentukan kemampuan campuran untuk menahan rutting.

Dalam kajian ini digunakan aditif Zycotherm untuk memproduksi campuran beraspal hangat (Warm Mix Asphalt WMA), diharapkan dengan menggunakan bahan aditif Zycotherm pada campuran 
beton aspal dapat mengurangi kerusakan jalan tersebut.

Produk aditif Zydex merupakan produk berbasis Nanotechnology dengan ikatan kimia organosilane yang dikembangkan Zydex Industries, Gujarat India. Zycotherm dapat memberikan nilai keawetan yang lebih pada desain konstruksi jalan. Keunggulan aditif Zycotherm yaitu sebagai bahan aditif Warm Mix Asphalt memungkinkan pencampuran dan pemadatan dapat dilakukan pada suhu lebih rendah $30-35^{\circ} \mathrm{C}$ dari campuran HMA, mudah homogen dengan aspal, mudah larut dalam aspal, memberikan lapisan kimia untuk meningkatkan kerekatan aspal dengan permukaan agregat sehingga mengurangi pengelupasan akibat efek oksidasi, Zycotherm sebagai waterproving dengan nanotechology memberikan sifat tahan air dan tahan kelembaban dalam jangka panjang, efisiensi bahan bakar di AMP, tidak berbau dan ramah lingkungan sehingga dapat meningkatkan umur jalan serta mengurangi biaya perawatan rutin tiap tahunnya.

Campuran beraspal hangat merupakan teknologi yang sedang berkembang di mana campuran beraspal dapat dikerjakan pada temperatur pencampuran dan pemadatan yang lebih rendah dibandingkan campuran beraspal panas. Tujuan utama dari diproduksinya WMA ini adalah untuk menghasilkan campuran yang mempunyai kekuatan, durabilitas dan kinerja setara dengan campuran beraspal panas tetapi dengan mengurangi temperatur pemadatan dan pencampurannya (National Cooperative Highway Research Program, 2011).

Campuran beraspal hangat dengan aditif Sasobit ${ }^{\circledR}$ dan Rediset ${ }^{\circledR}$ dapat menurunkan temperatur pemadatan sampai $125^{\circ} \mathrm{C}$ tanpa adanya perubahan yang signifikan pada kepadatan, kekakuan campuran atau ketahanan terhadap deformasi permanen (Zaumanis, 2010).

Penggunaan bahan aditif Zycotherm dengan kadar $0,1 \%$ dan $0,15 \%$ pemadatan dapat dilakukan pada temperatur $20-30^{\circ} \mathrm{C}$ dibawah Hot Mix Asphalt (Ranka, 2012). Stabilitas Marshall karakteristik Marshall dapat ditingkatkan untuk campuran WMA dengan penambahan aditif Zycotherm (Sharanappanavar, 2016).

Rutting dalam lapisan beton aspal disebabkan oleh kombinasi densifikasi (perubahan volume) dan deformasi geser, baik yang dihasilkan dari beban berulang dari beban lalu lintas. Pengaruh komposisi campuran pada ketahanan terhadap deformasi permanen. Tingkat kenaikan akumulasi deformasi permanen dengan cepat meningkat pada suhu yang lebih tinggi, sehingga pengujian laboratorium dilakukan pada suhu yang lebih tinggi dari $50^{\circ} \mathrm{C}$. Hasil pengujian alat Hamburg Wheel Tracking yang dilakukan sampai 20.000 siklus, campuran hangat menggunakan Zycotherm dengan suhu pencampuran $135^{\circ} \mathrm{C}-140^{\circ} \mathrm{C}$ menunjukkan ketahanan yang lebih baik terhadap deformasi permanen dan rutting dibandingkan $\mathrm{Hot}$ Mix Asphalt (155-150 ${ }^{\circ} \mathrm{C}$ ) (Gangopadhyay, et al., 2015).

Suparyanto, (2008) mengevaluasi pengaruh penggunaan Aspal Pertamina AC 60/70 dan Aspal Shell AC 60/70 terhadap deformasi permanen dengan menggunakan alat Wheel Tracking Machine, hasil pengujian Wheel Tracking menunjukkan bahwa peningkatan temperatur pemadatan berdasarkan viskositas 3,75 Pa.s, 0,72 Pa.s dan 0,4 Pa.s pada campuran AC-WC dengan bahan ikat aspal Pertamina maupun Shell meningkatkan ketahanan terhadap deformasi ditandai dengan menurunnya nilai deformasi permanen dan tingkat 
deformasi (Rate of Deformation) serta meningkatkan Stabilitas Dinamis (Dinamic of Stability).

Temperatur perkerasan di Indonesia rentang nya cukup tinggi, dan temperatur maksimum mencapai sekitar $60^{\circ} \mathrm{C}$ hingga $69^{\circ} \mathrm{C}$. Berdasarkan data temperatur perkerasan pada ruas jalan di Indonesia, yang diwakili dengan data dari beberapa kota maka aspal Pen 60 sebagai bahan pengikat sebaiknya digunakan pada ruas jalan yang memiliki temperatur perkerasan maksimum $55^{\circ} \mathrm{C}$, sedangkan untuk ruas jalan yang memiliki temperatur perkerasan diatas $55^{\circ} \mathrm{C}$ sebaiknya menggunakan aspal polimer atau beton aspal modifikasi (Sjahdanulirwan \& Nono, 2010). Pada temperatur $60^{\circ} \mathrm{C}$ menunjukkan nilai deformasi lebih tinggi dari pada pengujian pada temperatur $25^{\circ} \mathrm{C}$, hal ini disebabkan oleh viskositas aspal yang menyelimuti agregat semakin berkurang sehingga akan menurunkan ikatan antara agregat yang pada akhirnya akan meningkatkan nilai deformasi campuran (Dandamanu, 2003).

Selain kajian skala laboratorium, kajian teknologi campuran beraspal hangat ini juga telah dilaksanakan di lapangan untuk lalulintas sedang, menggunakan bahan tambah Zeolit alam yang telah di aktivasi dan Leadcap yang berlokasi di daerah Subang lokasi percobaan terletak di ruas Subang-Pagaden (Pamanukan) sepanjang $225 \mathrm{~m}$. Sedangkan untuk lalu lintas berat menggunakan bahan tambah wax ditambah SBS guna meningkatkan sifat aspal setara dengan aspal modifikasi berlokasi di daerah Jatibarang lokasi percobaan terletak di ruas Pantura bagian jalan By Pass Jatibarang arah ke Cirebon sepanjang 150 m (Affandi, 2015).

European Asphalt Pavement Association (2014) dapat dijelaskan, di Eropa semakin banyak negara memproduksi WMA dengan proses yang berbeda. Beberapa negara yang sudah melakukan kajian dan menerapkan teknologi Warm Mix Asphalt sejak tahun 1998 seperti Jerman, Republik Ceko, Denmark, Perancis, Norwegia, Swedia, Turki. Negara Amerika Serikat penggunaan WMA meningkat lebih cepat daripada di Eropa.

Ziari, et al., (2016), menyatakan bahwa Zycotherm tidak mengubah viskositas pengikat asli secara signifikan. Bahwa batasan viskositas aspal untuk penentuan temperatur pencampuran dan pemadatan yang umum selama ini digunakan tidak dapat diterapkan untuk campuran beraspal dengan bahan tambah, tidak terlihat adanya pola yang konsisten dari pengaruh bahan tambah terhadap korelasi temperatur dan viskositas aspal (Kusnianti \& Affandi, 2013)

Wahyudi, (2000) hasil kajian di laboratorium memperlihatkan bahwa teknik pemadatan tekan-putar (Gyropac) menghasilkan benda-uji yang relatif lebih baik karakteristiknya dibandingkan teknik pemadatan yang lain. Hubungan antara jumlah putaran dengan tinggi benda uji padat pada teknik pemadatan tekan-putar dapat digunakan untuk mengukur kemudahan kerja campuran. Gyropac memiliki nilai lebih dibanding alat pemadatan yang lain, yaitu mampu mencetak ulang (replika) benda uji dengan baik, dan dapat digunakan untuk mengevaluasi kemudahan kerja campuran aspal.

Uji Marshall adalah standar pengujian yang digunakan untuk campuran aspal panas dengan ukuran agregat maksimum $25 \mathrm{~mm}$ (ASTM D 1559). Metode Uji Marshall menggunakan benda uji dengan tinggi 64 $\mathrm{mm}$ (2,5 inch) dan diameter 101,6 mm (4 inch) yang dilakukan pengujian pada suhu $60^{\circ} \mathrm{C}$. Metode pengujian Marshall adalah suatu metode pengujian yang dilakukan untuk mengukur beban maksimum yang 
dapat dipikul benda uji sebelum hancur (Marshall Stability) dan deformasi permanen dari suatu benda uji sebelum hancur (Marshall Flow) serta turunannya yang merupakan perbandingan diantara keduanya yang disebut dengan Marshall Quotient (MQ). Metode yang digunakan dalam kajian ini berdasarkan RSNI M-012003, merupakan metode paling umum yang telah distandarisasikan dalam American Society for Testing and Material 1993 (ASTM D 1553).

Kajian ini bertujuan untuk mengetahui workability dengan membandingkan dan menganalisis stabilitas Marshall dan ketahanan deformasi menggunakan bahan aditif Zycotherm pada beton aspal lapis aus (AC-WC) campuran beraspal panas (hot mix) dan hangat (warm mix) dengan pengujian laboratorium di Pusat Kajian dan Pengembangan Jalan dan Jembatan (PUSJATAN) Bandung menggunakan alat Gyratory Compactor (Gyropac), Marshall dan Wheel Tracking Machine (WTM).

\section{METODE}

Secara garis besar kajian ini dimulai dengan melakukan studi literatur terhadap beberapa kajian-kajian terdahulu yang berhubungan dengan pengujian campuran beraspal hangat. Langkah selanjutnya adalah mempersiapkan material yang berkaitan dengan kajian ini. Aspal, agregat dan bahan tambah yang digunakan kemudian diuji properties dan harus memenuhi ketentuan pada Spesifikasi Umum Edisi 2010 Revisi 3 (2014).

Aspal yang digunakan adalah aspal Pen 60/70 produksi Shell yang didistribusikan oleh PT. Buntara Megah Inti. Agregat digunakan agregat kasar dan agregat halus dari batu pecah (Stone Crusher) yang berasal dari Clereng, Kulon Progo,
Yogyakarta. Zat aditif yang digunakan adalah Zycotherm yang diperoleh dari PT. Jaya Trade Indonesia. Masing-masing bahan kemudian dicampur menjadi suatu sampel campuran untuk diuji di laboratorium menggunakan alat Marshall dan Wheel Tracking pada kondisi kadar aspal optimum (KAO). Hasil pengujian stabilitas Marshall dilihat perbadingan nilai stabilitasnya dan Wheel Tracking (WTM) kemudian dibandingkan parameter dari pengujian tersebut seperti Deformasi (D0), Dynamic Stabiblity (DS), Rate of Deformation (RD). Kemudian hasil pengujian terebut dilakukan analisis dan diambil suatu kesimpulan sesuai dengan tujuan kajian.

Kusnianti \& Affandi, (2013) menjelaskan prinsip dari pemadatan dengan alat Gyratory Compactor Machine (GCM) ini, yaitu dengan memberikan tekanan vertikal yang konstan dan pada waktu yang bersamaan dilakukan dilakukan pemberian gaya dinamis sehingga berupa gaya pemadatan bukan tumbukan dengan sudut girasi sebesar 2 derajat. Pada pengkajian ini pemadatan dengan Gyropac dilakukan dengan beban vertikal sebesar $240 \mathrm{kPa}$, sudut girasi sebesar 2 derajat dan kecepatan girasi 60 RPM. Pemadatan dengan cara ini merupakan simulasi dari cara pemadatan yang dilakukan di lapangan. Selama pemadatan tinggi benda uji diukur secara otomatis dan dicatat menggunakan pengukur dial Gyropac setiap 25 girasi, sesuai dengan jumlah girasi yang sedang berjalan.

Metode yang di kembangkan oleh (Cabrera \& Dixon, 1994) dalam (Kusnianti \& Affandi, 2013) untuk mengukur workabilitas campuran dengan menggunakan besaran Workability index (WI) yang merupakan kebalikan dari sifat rongga dalam campuran dimana perputaran atau girasinya sama dengan nol. 
Pengujian Workability dengan Gyropac, pengujian ini untuk mengetahui kemudahan dalam mengerjakan dan melihat pengaruh temperatur pencampuran dan pemadatan terhadap Workability campuran yang dikaitkan dengan penambahan Zycotherm. Pengujian dilakukan terhadap empat (4) variasi campuran yaitu AC-WC HMA-0, WMA-1, WMA-2, dan WMA-3 pada kadar aspal perkiraan $(\mathrm{Pb}) \quad 6,0 \%$. Temperatur pencampuran dilakukan dengan variasi penurunan tiap $10^{\circ} \mathrm{C}$ yaitu $140^{\circ} \mathrm{C}, 130^{\circ} \mathrm{C}$, $120^{\circ} \mathrm{C}, 110^{\circ} \mathrm{C}$ dan $100^{\circ} \mathrm{C}$. Demikian halnya dengan temperatur pemadatan dimulai dari variasi penurunan $10^{\circ} \mathrm{C}$ yaitu $130^{\circ} \mathrm{C}$, $120^{\circ} \mathrm{C}, 110^{\circ} \mathrm{C}, 100^{\circ} \mathrm{C}$ dan $90^{\circ} \mathrm{C}$ secara berturutan. Hasil pengujian dapat dilihat pada Tabel 1, Tabel 2 dan Tabel 3, yang selanjutnya digambarkan seperti pada Gambar 2.

Tabel 1. Nilai WI HMA dan 0,10\% Zycotherm

Temperatur Pencampuran dan Pemadatan HMA Campuran Zycotherm 0,1\%

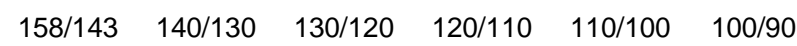

\begin{tabular}{lllllll}
\hline $\mathbf{3 , 7 5 6}$ & 3,458 & $\mathbf{3 , 6 0 0}$ & 3,410 & 3,398 & 3,420
\end{tabular}

Tabel 2. Nilai WI HMA dan 0,15\% Zycotherm

Temperatur Pencampuran dan Pemadatan

HMA Campuran Zycotherm 0,15\%

\begin{tabular}{llllll}
$158 / 143$ & $140 / 130$ & $130 / 120$ & $120 / 110$ & $110 / 100$ & $100 / 90$ \\
\hline
\end{tabular}

$\begin{array}{llllll}\mathbf{3 , 7 5 6} & 3,602 & \mathbf{3 , 5 7 1} & 3,485 & 3,444 & 3,472\end{array}$

Tabel 3. Nilai WI HMA dan 0,20\% Zycotherm

Temperatur Pencampuran dan Pemadatan

HMA Campuran Zycotherm 0,20\%

$158 / 143 \quad 140 / 130 \quad 130 / 120 \quad 120 / 110 \quad 110 / 100 \quad 100 / 90$

$\begin{array}{lllllll}\mathbf{3 , 7 5 6} & \mathbf{3 , 6 9 8} & 3,449 & 3,298 & 3,388 & 3,308\end{array}$

Gambar 2. Hubungan antara Temperatur dan Workability index (WI)

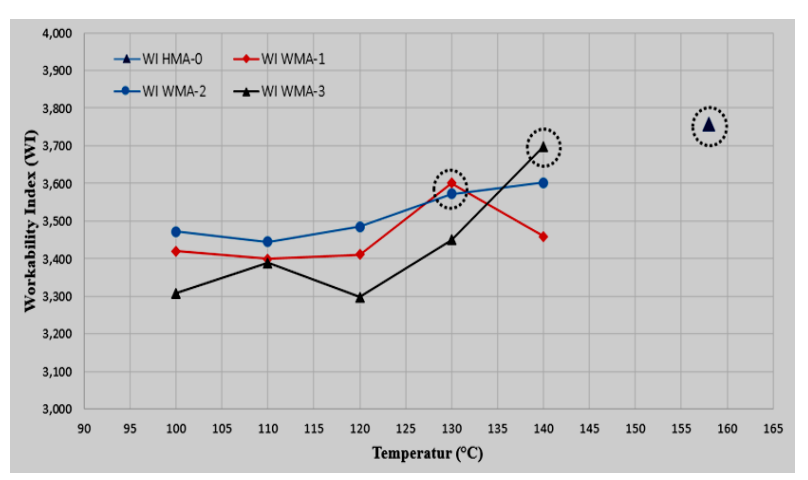

Berdasarkan Tabel 1 - Tabel 3 dan Gambar 2, hasil pengujian Gyropac dengan berbagai campuran AC-WC HMA0, WMA-1, WMA-2 dan WMA-3. Secara umum, dapat dikatakan bahwa nilai WI menggunakan aditif Zycotherm dalam campuran hangat, bila di bandingkan dengan campuran panas sebagai kontrol (HMA-0), menunjukkan nilai WI yang dihasilkan tidak berbeda secara signifikan dengan range WI 3,0 - 3,7. Hal ini dapat berarti walaupun campuran hangat dilaksanakan dibawah suhu yang lebih rendah masih mempunyai tingkat Workability yang baik, ini juga dimungkinkan karena menggunakan jenis gradasi dan kadar aspal $\mathrm{Pb}(6 \%)$ yang sama di setiap campuran.

Pada kajian ini dibatasi ruang lingkup hanya menggunakan satu (1) temperatur pencampuran dan pemadatan di setiap variasi campuran, dalam hal ini akan di pilih nilai WI campuran hangat yang paling mendekati nilai WI kontrol (HMA-0). Suhu pencampuran dan pemadatan campuran WMA-1, WMA-2 dan WMA-3 sehingga secara berurutan diperoleh suhu $130 / 120^{\circ} \mathrm{C}, 130 / 120^{\circ} \mathrm{C}$ dan $140 / 130^{\circ} \mathrm{C}$, untuk lebih jelasnya dapat dilihat pada Tabel 4.

Dalam kajian ini dibuat empat (4) variasi campuran dengan menggunakan aspal pen 60/70 (ex Shell) dan aditif Zycotherm. Kajian ini juga terdiri dari komposisi campuran, suhu pencampuran dan pemadatan yang berbeda beda yaitu pada campuran HMA-0, WMA-1, WMA-2 dan 
WMA-3, untuk lebih jelasnya dapat dilihat dalam Tabel 4.

Tabel 4. Variasi campuran berdasarkan variasi aditif Zycotherm

\begin{tabular}{ll}
\hline $\begin{array}{l}\text { Variasi } \\
\text { / KAO }\end{array}$ & \multicolumn{1}{c}{$\begin{array}{c}\text { Komposisi Campuran \& } \\
\text { Suhu Pencampuran dan } \\
\text { Pemadatan }\end{array}$} \\
\hline HMA-0 & Campuran AC-WC menggunakan aspal \\
$\mathbf{5 , 7 0 \%}$ & Pen. 60/70, (158/143) $)^{\circ} \mathrm{C}$ \\
WMA-1 & Campuran AC-WC + aspal Pen. 60/70 \\
$\mathbf{6 , 1 0 \%}$ & dan aditif Zycotherm 0,1\%, (130/120 $)^{\circ} \mathrm{C}$ \\
WMA-2 & Campuran AC-WC + aspal Pen. 60/70 \\
$\mathbf{5 , 9 0 \%}$ & dan aditif Zycotherm 0,15\%, \\
WMA-3 & $(130 / 120)^{\circ} \mathrm{C}$ \\
$\mathbf{5 , 9 0 \%}$ & Campuran AC-WC + aspal Pen. 60/70 \\
& dan aditif $Z y c o t h e r m ~ 0,2 \%,(140 / 130)^{\circ} \mathrm{C}$ \\
\hline
\end{tabular}

Sebelum pengujian Wheel Tracking dilakukan, terlebih dahulu dipersiapkan campuran beton aspal untuk pembuatan benda uji. Persiapan campuran beton aspal dilakukan dengan menghitung jumlah bahan yang diperlukan baik agregat maupun keperluan jumlah aspal pada kadar aspal optimum (KAO). Jumlah bahan yang diperlukan disesuaikan dengan volume benda uji yaitu sesuai dengan ukuran cetakan $30 \times 30 \times 5\left(\mathrm{~cm}^{3}\right)$. Proses berikutnya agregat dan aspal dicampur pada kadar aspal optimum (KAO) dengan suhu pencampuran dan pemadatan campuran Hot Mix Asphalt (HMA) dan Warm Mix Asphalt (WMA) masing-masing variasi dengan alat pencampur (mixer) elektrik yang dilengkapi dengan pengatur panas sehingga suhu pencampuran tetap terjaga. Selanjutnya dibuat benda uji pada

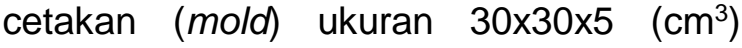
dipadatkan pada temperatur sesuai variasi campuran menggunakan alat pemadat Wheel Tracking Compactor sampai kepadatan yang diinginkan tercapai yaitu berdasarkan tinggi benda uji. Toleransi kepadatan yang masih diterima sebesar $2 \%$ atau $5 \pm 0,2 \mathrm{~cm}$.

Komponen utama dari Wheel Tracking Test adalah Wheel Tracking Compactor (alat pemadat benda uji) dan Wheel Tracking Machine (mesin penguji). Wheel Tracking Machine (WTM) adalah alat yang mempunyai sebuah roda yang bergerak maju mundur membebani benda uji yang berukuran $30 \times 30 \times 5\left(\mathrm{~cm}^{3}\right)$ dan digunakan untuk memperkirakan ketahanan benda uji terhadap deformasi permanen.

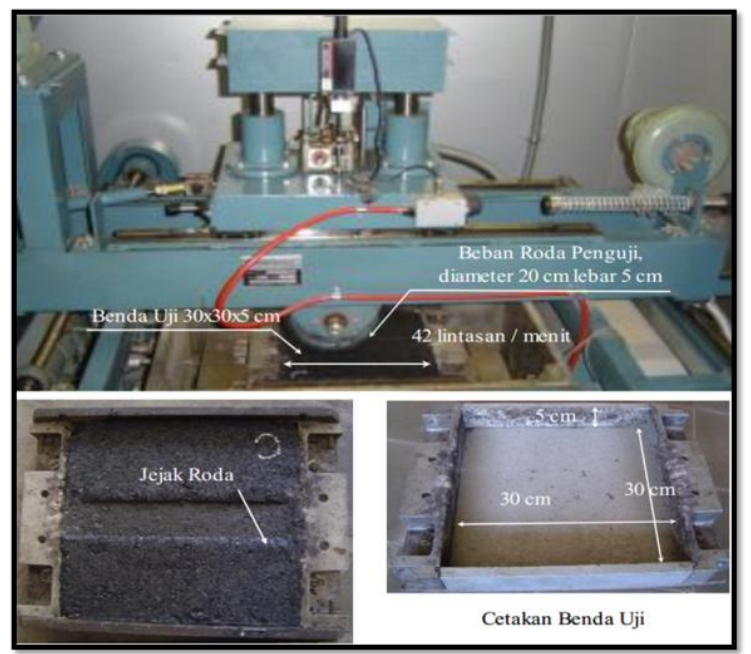

Gambar 3. Alat Pengujian Wheel Tracking

Prosedur pengujian sesuai Manual for Design and Construction of Asphalt Pavement - Japan Road Association, JRA (1998) adapun langkah-langkah pengujian Wheel Tracking Machine (WTM) adalah sebagai berikut :

1. Pelaksanaan pengujian dilakukan di laboratorium dalam ruang dengan temperatur yang disesuaikan dengan kondisi lapangan. Pada kajian ini dilakukan dalam kondisi benda uji kering dengan temperatur pengujian dilakukan berdasarkan Spesifikasi Umum Bina Marga Edisi 2010 revisi 3 (2014) dan literatur lainnya temperatur perkerasan di Indonesia sekitar $60^{\circ} \mathrm{C}$, pengujian dilakukan pada temperatur $60^{\circ} \mathrm{C}$ yang dimaksudkan untuk lebih 
melihat pengaruh temperatur terhadap kinerja campuran. Agar temperatur benda uji seragam maka benda uji tersebut diletakkan dalam ruangan uji pada temperatur pengujian selama 6 jam.

2. Pengujian dilakukan dengan tekanan permukaan sebesar $6,4 \pm 0,15 \mathrm{~kg} / \mathrm{cm}^{2}$, yang setara dengan beban sumbu tunggal roda ganda 8,16 ton. Masingmasing benda uji diuji dengan 1.260 siklus roda dalam 60 menit, yaitu dengan 21 siklus (42 lintasan) per menit.

3. Pembebanan pada pengujian Wheel Tracking ini dilakukan melalui roda karet bergerak maju mundur.

4. Dalamnya alur (deformasi) tercatat melalui sensor yang ada pada tungkai roda pembebanan yang dihubungkan dengan alat kontrol dan data yang dihasilkan berupa waktu pembebanan, jumlah lintasan, kedalaman alur, kecepatan deformasi, dan stabilitas dinamis.

\section{HASIL DAN PEMBAHASAN}

Hasil pengujian sifat fisik aspal dan agregat seperti diperlihatkan pada Tabel 6 dan Tabel 7, menunjukkan bahan yang digunakan untuk kajian ini memenuhi persyaratan Spesifikasi Umum Direktorat Jenderal Bina Marga Edisi 2010 Revisi 3 (2014).

Tabel 5. Hasil Pengujian Karakteristik Aspal Penetrasi 60/70

\begin{tabular}{lcc}
\hline Jenis Pengujian & Spesifikasi & $\begin{array}{c}\text { Hasil } \\
\text { Pengujian }\end{array}$ \\
\hline Penetrasi pada & $60-70$ & 64,0 \\
$\mathbf{2 5}{ }^{\circ} \mathbf{C}$ & $\geq 48$ & 49,5 \\
Titik Lembek $\left({ }^{\circ} \mathbf{C}\right)$ & $\geq 100$ & $>100$ \\
Daktilitas $(\mathbf{c m})$ & $\geq 232$ & 332 \\
Titik Nyala $\left({ }^{\circ} \mathbf{C}\right)$ & $\geq 99$ & 99,69 \\
Kelarutan dalam & & \\
\hline
\end{tabular}

\begin{tabular}{lcc}
\hline Jenis Pengujian & Spesifikasi & $\begin{array}{c}\text { Hasil } \\
\text { Pengujian }\end{array}$ \\
\hline TCE (\%) & $\geq 1,0$ & 1,039 \\
Berat Jenis (\%) & & \\
\hline
\end{tabular}

Berdasarkan Tabel 5. hasil pengujian mutu aspal diperoleh hasil bahwa aspal dapat digunakan sebagai bahan campuran beraspal, sesuai dengan persyaratan Spesifikasi Umum Direktorat Jenderal Bina Marga Edisi 2010 Revisi 3 (2014).

Tabel 6. Hasil Pengujian Karakteristik Agregat

\begin{tabular}{lcc}
\hline \multicolumn{1}{c}{ Pengujian } & Spesifikasi & $\begin{array}{c}\text { Hasil } \\
\text { Pengujian }\end{array}$ \\
\hline Abrasi dengan mesin Los & Maks. 30\% & 23,40 \\
Angeles & $100 / 90$ & $100 / 96,46$ \\
Angularitas & Maks. 5\% & 3,766 \\
Partikel pipih dan lonjong & & \\
(perbandingan 1:5) & -- & 2,663 \\
Berat Jenis Agregat Kasar & & \\
\hline Nilai Setara Pasir & Min. 60\% & 68,330 \\
Material lolos Ayakan No. & Maks. 1\% & 0,942 \\
200 & -- & 2,667 \\
Berat Jenis Agregat Halus & & \\
\hline Berat Jenis Filler debu Batu & -- & 2,668 \\
\hline
\end{tabular}

Berdasarkan Tabel 6. hasil pengujian mutu aspal diperoleh hasil bahwa aspal dapat digunakan sebagai bahan campuran beraspal, sesuai dengan persyaratan Spesifikasi Umum Direktorat Jenderal Bina Marga Edisi 2010 Revisi 3 (2014).

Pengujian stabilitas bertujuan untuk mengukur ketahanan suatu campuran beton aspal terhadap deformasi selama pembebanan lalu lintas atau kemampuan maksimum dari suatu benda uji dalam menahan beban sampai terjadi kelelehan plastis. Nilai stabilitas didapatkan berdasarkan nilai yang ditunjukkan oleh jarum dial pada proving ring stabilitas yang dipasang pada alat Marshall Test. Nilai stabilitas ini kemudian dikonversikan dengan Tabel Kalibrasi sesuai proving ring 
yang digunakan, selanjutnya nilai Stabilitas tersebut harus dikoreksi dengan suatu faktor koreksi ketebalan benda uji sesuai Persamaan berikut :

$\mathrm{MS}=\mathrm{n} \times$ koreksi benda uji

Dengan:

MS : stabilitas Marshall $(\mathrm{kg})$

$\mathrm{n} \quad$ : $\mathrm{m} \times$ kalibrasi proving ring

$m$ : nilai pembacaan arloji stabilitas Marshall

Tabel 7. Hasil Pengujian Stabilitas Marshall HMA- WMA- WMA- WMA-

\begin{tabular}{ccccc} 
Rendaman & 0 & 1 & 2 & 3 \\
\cline { 2 - 5 } $60^{\circ} \mathrm{C}$ & \multicolumn{4}{c}{ Stabilitas $(\mathrm{Kg})$} \\
\cline { 2 - 5 } & 1310 & 1325 & 1298 & 1236 \\
\hline
\end{tabular}

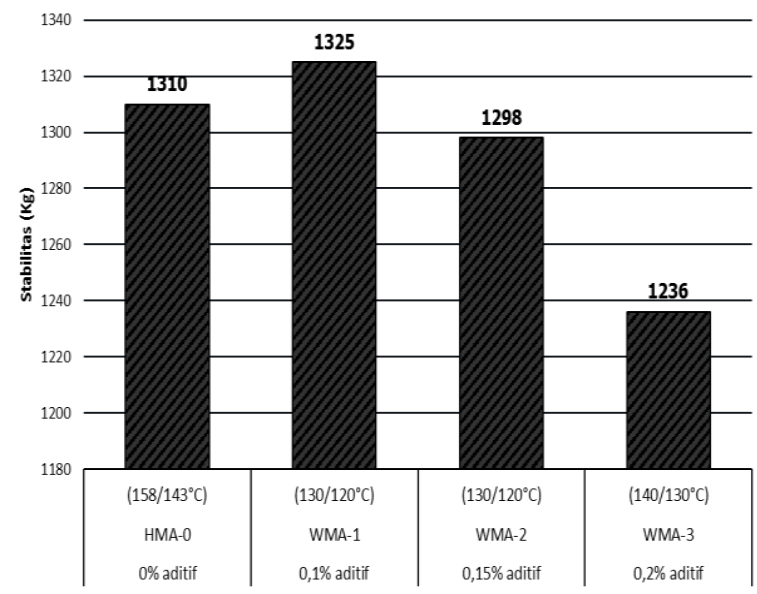

Gambar 4. Perbandingan Stabilitas Marshall

Berdasarkan Tabel 7 dan Gambar 4, Hasil pengujian Marshall pada campuran beraspal panas (Hot Mix Asphalt) maupun beraspal hangat (Warm Mix Asphalt) dengan empat variasi campuran menunjukkan Nilai stabilitas Marshall variasi campuran AC-WC HMA-0, WMA-1, WMA-2 dan WMA-3 memenuhi persyaratan spesifikasi yaitu minimum 800 Kg. Nilai stabilitas Marshall pada aspal Pen 60/70 (HMA-0) adalah 1310 kg, aditif Zycotherm 0,1\% (WMA-1) adalah $1325 \mathrm{~kg}$, aditif Zycotherm 0,15\% (WMA-2) adalah $1298 \mathrm{~kg}$, dan aditif Zycotherm 0,20\%
(WMA-3) adalah $1236 \mathrm{~kg}$, nilai stabilitas terbesar diperoleh pada campuran WMA-1. Dari pengujian Marshall dapat diketahui bahwa penambahan kadar aditif Zycotherm pada campuran hangat (Warm Mix Asphalt) AC-WC mempengaruhi nilai stabilitas Marshall yaitu dengan peningkatan kadar aditif Zycotherm, nilai stabilitas mengalamai penurunan. Hal ini dapat disimpulkan bahwa penggunaan aspal serta penambahan Zycotherm cocok digunakan pada campuran hangat AC-WC, dengan nilai optimum penggunaan Zycotherm sebanyak 0,1\%. Penggunaan kadar Zycotherm yang berlebihan menghasilkan performa campuran hangat AC-WC yang kurang baik. Penambahan aditif Zycotherm dapat menjaga stabilitas walaupun dilakukan penurunan temperatur pencampuran dan pemadatan dibawah $\mathrm{Hot}$ Mix Asphalt.

Pengujian Wheel Tracking dilakukan pada suhu $60^{\circ} \mathrm{C}$ dengan 4 (empat) variasi campuran. Benda uji dibuat pada kondisi kadar aspal optimum (KAO). Untuk melihat kinerja ketahanan deformasi campuran dilakukan tinjauan terhadap tiga parameter yaitu kedalaman alur atau deformasi dalam satuan $\mathrm{mm}$ setelah dilalui sejumlah lintasan, Laju Deformasi (RD, Rate of Deformation) dalam satuan $\mathrm{mm} /$ menit. Di samping itu juga dapat diukur nilai Stabilitas Dinamis / Dynamic Stability (DS) dalam lintasan/mm, yang dapat dihitung dengan menggunakan persamaan :

$$
\begin{aligned}
& D S=42 \times \frac{\left(t_{2}-t_{1}\right)}{\left(d_{2}-d_{1}\right)} \\
& R D=\frac{\left(d_{2}-d_{1}\right)}{\left(t_{2}-t_{1}\right)}
\end{aligned}
$$

\section{Dengan:}

DS : Stabilitas dinamis (lintasan/mm)

RD : Kecepatan deformasi ( $\mathrm{mm} /$ menit)

$\mathrm{d}_{1}$ : Deformasi saat pengujian pada menit $45(\mathrm{~mm})$ 
$d_{2}$ : Deformasi saat pengujian pada menit $60(\mathrm{~mm})$

$\mathrm{t}_{1} \quad$ : Waktu pengujian 45 menit

$\mathrm{t}_{2}$ : Waktu pengujian 60 menit

Hasil pengujian deformasi permanen dengan menggunakan alat Wheel Tracking Machine (WTM) pada campuran panas dan hangat dapat dilihat pada Tabel 10, Gambar 4 dan Gambar 5.

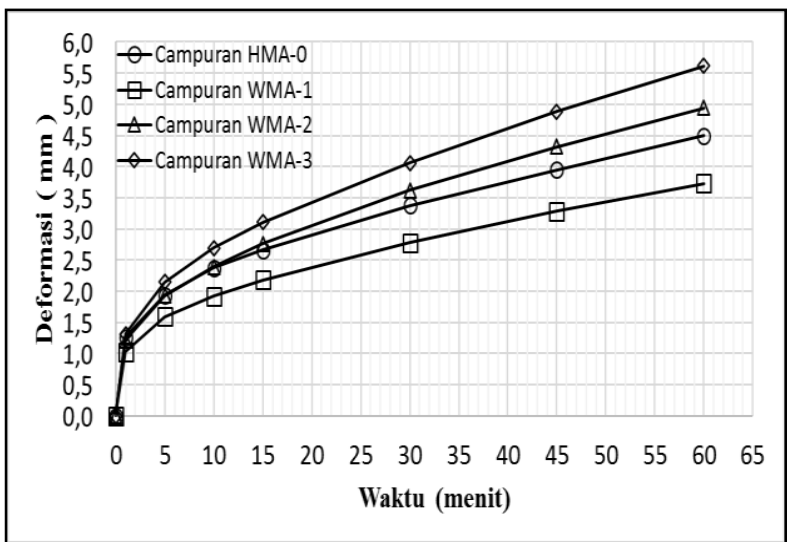

Gambar 5. Hasil Pengujian Hubungan antara Waktu dan Deformasi

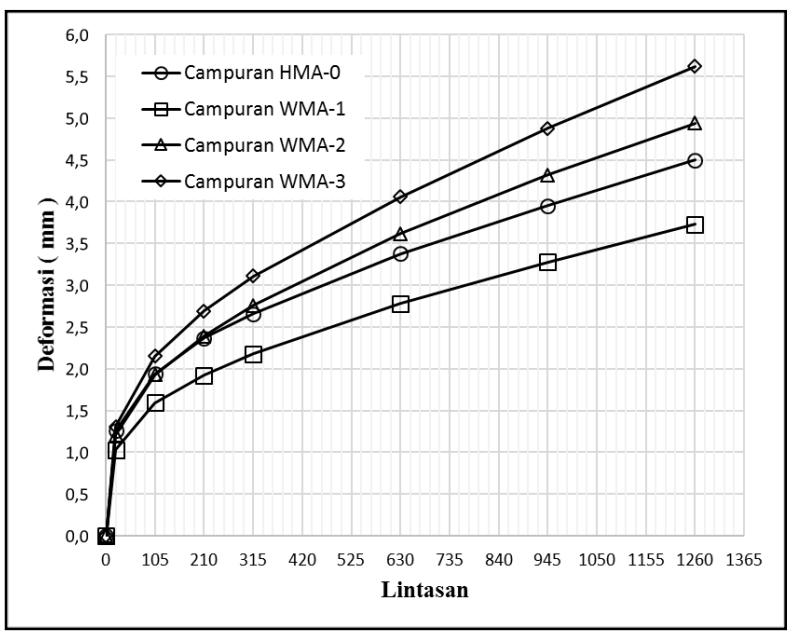

Gambar 6. Hasil Pengujian Hubungan antara Jumlah Lintasan dan Deformasi

Nilai parameter dari pengujian Wheel Tracking Machine juga dapat dihitung dengan menggunakan persamaan (2) dan (3) dapat dilihat pada Tabel 9.

Tabel 8. Hasil Pengujian dengan Wheel Tracking Machine

\begin{tabular}{|c|c|c|c|c|c|}
\hline \multirow[b]{2}{*}{ Waktu } & \multirow[b]{2}{*}{ Lintasan } & \multicolumn{4}{|c|}{ Deformasi (mm) } \\
\hline & & $\begin{array}{c}\text { HMA- } \\
0\end{array}$ & $\begin{array}{c}\text { WMA- } \\
1\end{array}$ & $\begin{array}{c}\text { WMA- } \\
2\end{array}$ & $\begin{array}{c}\text { WMA- } \\
3\end{array}$ \\
\hline 0 & 0 & 0,00 & 0,00 & 0 & 0 \\
\hline 1 & 21 & 1,26 & 1,03 & 1,21 & 1,31 \\
\hline 5 & 105 & 1,94 & 1,59 & 1,93 & 2,15 \\
\hline 10 & 210 & 2,37 & 1,92 & 2,39 & 2,69 \\
\hline 15 & 315 & 2,66 & 2,18 & 2,76 & 3,11 \\
\hline 30 & 630 & 3,38 & 2,78 & 3,62 & 4,06 \\
\hline 45 & 945 & 3,95 & 3,28 & 4,32 & 4,88 \\
\hline 60 & 1260 & 4,50 & 3,73 & 4,94 & 5,62 \\
\hline \multicolumn{2}{|c|}{ D0 (mm) } & 2,30 & 1,93 & 2,46 & 2,66 \\
\hline \multicolumn{2}{|c|}{$\mathrm{RD}$ (mm/menit) } & 0,0367 & 0,030 & 0,0413 & 0,0493 \\
\hline \multicolumn{2}{|c|}{ DS } & 1145,5 & 1400 & 1016,1 & 851,4 \\
\hline
\end{tabular}

Tabel 9. Hasil Perhitungan Pengujian dengan Wheel Tracking Machine

\begin{tabular}{ccccc}
\hline \multirow{2}{*}{ Parameter } & \multicolumn{4}{c}{ Hasil Perhitungan } \\
\cline { 2 - 5 } & $\mathbf{H M A}-$ & WMA- & WMA-2 & WMA-3 \\
& $\mathbf{0}$ & $\mathbf{1}$ & & \\
\hline $\mathbf{d}_{\mathbf{1}}$ & 3,95 & 3,28 & 4,32 & 4,88 \\
$\mathbf{d}_{\mathbf{2}}$ & 4,50 & 3,73 & 4,94 & 5,62 \\
$\mathbf{t}_{1}$ & 45 & 45 & 45 & 45 \\
$\mathbf{t}_{2}$ & 60 & 60 & 60 & 60 \\
\hline $\mathbf{R D}$ & 0,0367 & 0,030 & 0,0413 & 0,0493 \\
$\mathbf{D S}$ & 1145,5 & 1400 & 1016,1 & 851,4 \\
\hline
\end{tabular}




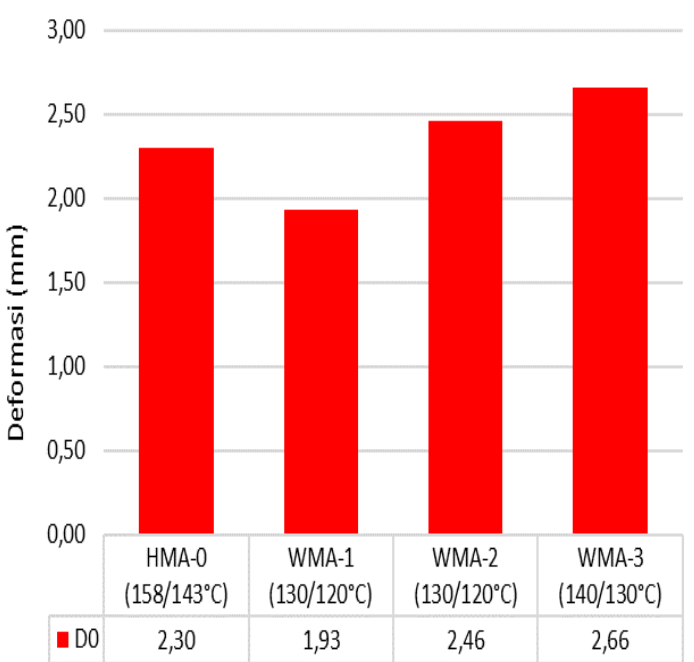

Gambar 7. Perbandingan Nilai Deformasi Campuran HMA dan WMA

Berdasarkan Gambar 5, Gambar 6 dan Gambar 7, dapat dijelaskan bahwa semakin lamanya waktu pembebanan dan jumlah lintasan berulang yang dilakukan terhadap campuran menunjukkan peningkatan deformasi yang terjadi terlihat dari kurva hubungan waktu pembebanan, jumlah lintasan dan nilai deformasi, campuran dengan nilai deformasi terendah hingga tertinggi secara berurutan yaitu campuran WMA-1, HMA-0, WMA-2 dan WMA-3 dengan masing nilai deformasi sebesar 1,93 mm, 2,30 mm, 2,46 mm dan 2,66 mm. Pada campuran hangat nilai deformasi akan meningkat seiring dengan peningkatan kadar aditif Zycotherm dalam campuran hangat, bila di bandingkan deformasi yang terjadi pada campuran panas sebagai kontrol, hasil menunjukkan tidak terdapat perbedaan yang signifikan dengan range deformasi $1,93 \mathrm{~mm}-2,66$ $\mathrm{mm}$, yang artinya walaupun campuran hangat dilaksanakan dibawah suhu yang lebih rendah masih mempunyai ketahanan deformasi yang baik. Hal tersebut dikarenakan fungsi Zycotherm selain sebagai aditif warm mix, Zycotherm mudah larut dalam aspal memberikan lapisan kimia untuk meningkatkan kerekatan aspal dengan permukaan agregat sehingga mengalami penurunan (deformasi). Dari Gambar 3 terlihat jelas campuran AC-WC WMA-1 mempunyai hasil deformasi yang paling kecil yaitu $1,93 \mathrm{~mm}$ dengan demikian campuran hangat kadar aditif $0,1 \%$ mempunyai ketahanan yang lebih baik terhadap deformasi dibandingkan campuran HMA-0, WMA-2 dan WMA-3.

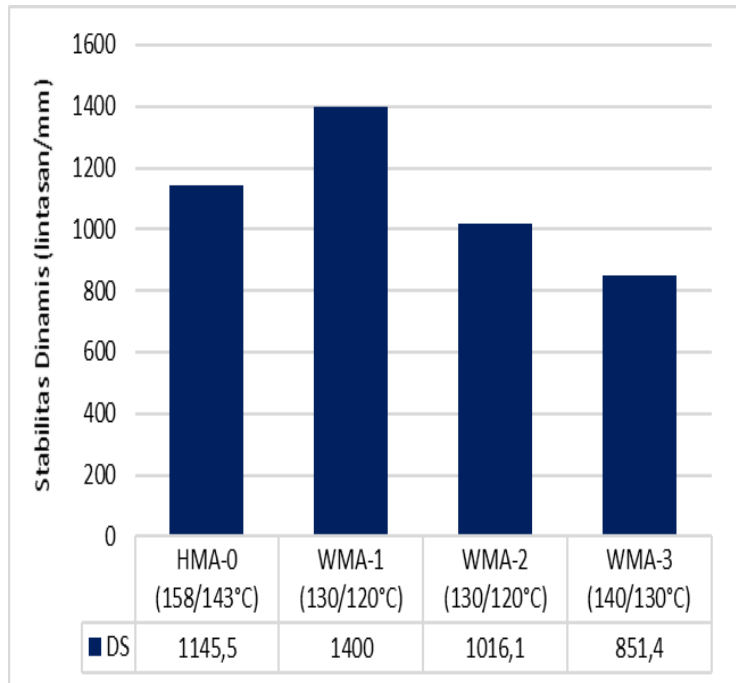

Gambar 8. Perbandingan Nilai Stabilitas Dinamis Campuran HMA dan WMA

Berdasarkan Tabel 8 dan Gambar 8, dapat dijelaskan bahwa pada campuran hangat semakin bertambahnya kadar aditif Zycotherm menunjukkan trend penurunan nilai stabilitas dinamis, Dari Gambar 4 terlihat jelas campuran AC-WC WMA-1 mempunyai stabilitas dinamis yang paling besar yaitu 1400 lintasan/mm dengan demikian campuran hangat kadar aditif $0,1 \%$ mempunyai stabilitas dinamis yang lebih baik dibandingkan campuran HMA-0, WMA-2 dan WMA-3. Hal ini dimungkinkan berdasar kajian sebelumnya yang menyatakan bahwa penambahan aditif $0,1 \%$ merupakan kadar optimum aditif Zycotherm.

Berdasarkan Tabel 8 dan Gambar 9, dapat dijelaskan bahwa pada campuran hangat semakin bertambahnya kadar aditif Zycotherm menunjukkan trend kecepatan 
deformasi dalam satuan $\mathrm{mm} /$ menit semakin meningkat, Dari Gambar 4 terlihat jelas campuran AC-WC WMA-1 mempunyai nilai kecepatan deformasi yang paling kecil yaitu $0,030 \mathrm{~mm} /$ menit, dengan demikian campuran hangat kadar aditif $0,1 \%$ mempunyai kecepatan deformasi yang lebih kecil dibandingkan campuran HMA-0, WMA-2 dan WMA-3. Hal ini disebabkan campuran WMA-1 mempunyai stabilitas dinamis yang besar sehingga memperkecil kecepatan deformasi yang terjadi.

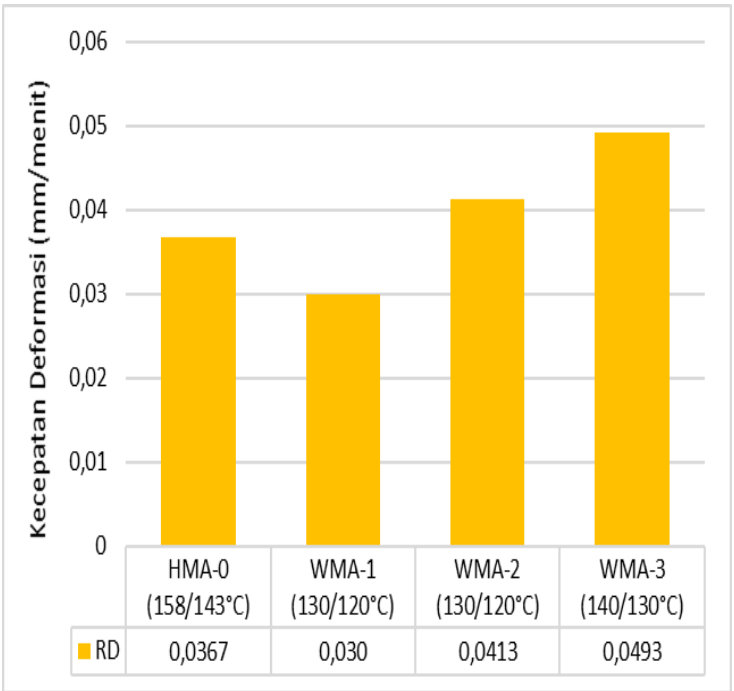

Gambar 9. Kecepatan Deformasi Campuran HMA dan WMA

\section{SIMPULAN}

Secara keseluruhan dapat ditarik kesimpulan perbandingan kinerja terhadap stabilitas Marshall dan ketahanan deformasi campuran panas dan hangat adalah sebagai berikut: 1) Berdasarkan hasil pengujian Gyropac, dengan pendekatan nilai workability index (WI) diperoleh suhu pencampuran dan pemadatan campuran WMA-1, WMA-2 dan WMA-3 secara berurutan diperoleh suhu $130 / 120^{\circ} \mathrm{C}, 130 / 120^{\circ} \mathrm{C}$ dan $140 / 130^{\circ} \mathrm{C}$; 2) Pengujian Marshall pada campuran beraspal panas (Hot Mix Asphalt) maupun beraspal hangat (Warm Mix Asphalt) dengan empat variasi campuran menunjukkan Nilai stabilitas Marshall variasi campuran AC-WC HMA-0, WMA-1, WMA-2 dan WMA-3 memenuhi persyaratan spesifikasi yaitu minimum 800 Kg. Nilai stabilitas Marshall pada aspal Pen 60/70 (HMA-0) adalah $1310 \mathrm{~kg}$, aditif Zycotherm 0,1\% (WMA-1) adalah $1325 \mathrm{~kg}$, aditif Zycotherm 0,15\% (WMA-2) adalah $1298 \mathrm{~kg}$, dan aditif Zycotherm 0,20\% (WMA-3) adalah $1236 \mathrm{~kg}$, nilai stabilitas terbesar diperoleh pada campuran WMA-1; 3) Penambahan kadar aditif Zycotherm pada campuran hangat (Warm Mix Asphalt) AC-WC mempengaruhi nilai stabilitas Marshall yaitu dengan peningkatan kadar aditif Zycotherm, nilai stabilitas mengalamai penurunan. Hal ini dapat disimpulkan bahwa penggunaan aspal serta penambahan Zycotherm cocok digunakan pada campuran hangat AC-WC, dengan nilai optimum penggunaan Zycotherm sebanyak $0,1 \%$. Penggunaan kadar Zycotherm yang berlebihan menghasilkan performa campuran hangat AC-WC yang kurang baik; 4) Pada campuran hangat nilai deformasi akan meningkat seiring dengan peningkatan kadar aditif Zycotherm dalam campuran hangat, bila di bandingkan deformasi yang terjadi pada campuran panas sebagai kontrol, hasil menunjukkan tidak terdapat perbedaan yang signifikan dengan range deformasi 1,93 mm - 2,66 mm; 5) Semakin lamanya waktu pembebanan berulang yang dilakukan terhadap campuran menunjukkan peningkatan deformasi yang terjadi terlihat dari kurva hubungan waktu pembebanan dan nilai deformasi, campuran dengan nilai deformasi terendah hingga tertinggi secara berurutan yaitu campuran WMA-1, HMA-0, WMA-2 dan WMA-3 dengan masing nilai deformasi sebesar 1,93 mm, 2,30 mm, 2,46 mm dan $2,66 \mathrm{~mm}$; 6) Campuran hangat semakin bertambahnya kadar aditif Zycotherm menunjukkan trend penurunan nilai 
Stabilitas Marshall dan ... (I Gusti/ hal. 48-61)

stabilitas dinamis, campuran AC-WC WMA-1 mempunyai stabilitas dinamis yang paling besar yaitu 1400 lintasan/mm dengan demikian campuran hangat kadar aditif $0,1 \%$ mempunyai stabilitas dinamis yang lebih baik dibandingkan campuran HMA-0, WMA-2 dan WMA-3. Hal ini dimungkinkan berdasar kajian sebelumnya yang menyatakan bahwa penambahan aditif $0,1 \%$ merupakan kadar optimum aditif Zycotherm; 7) Campuran hangat dengan semakin bertambahnya kadar aditif Zycotherm menunjukkan trend kecepatan deformasi dalam satuan $\mathrm{mm} /$ menit semakin meningkat, Dari Gambar 4 terlihat jelas campuran AC-WC WMA-1 mempunyai nilai kecepatan deformasi yang paling kecil yaitu $0,030 \mathrm{~mm} /$ menit, dengan demikian campuran hangat kadar aditif $0,1 \%$ mempunyai kecepatan deformasi yang lebih kecil dibandingkan campuran HMA-0, WMA-2 dan WMA-3. Hal ini disebabkan campuran WMA-1 mempunyai stabilitas dinamis yang besar sehingga memperkecil kecepatan deformasi yang terjadi; 8) Campuran aspal hangat WMA-1 memiliki nilai deformasi yang paling kecil sebesar $1,93 \mathrm{~mm}$, stabilitas dinamis 1400 lintasan $/ \mathrm{mm}$ dan kecepatan deformasi $0,030 \mathrm{~mm} /$ menit. hal ini disebabkan fungsi dari aditif Zycotherm bekerja secara optimum pada kadar $0,1 \%$ sehingga menghasilkan perkerasan yang paling baik di bandingkan campuran HMA-0 dengan nilai deformasi sebesar $2,30 \mathrm{~mm}$, stabilitas dinamis 1145,5 lintasan/mm dan kecepatan deformasi $0,0367 \mathrm{~mm} /$ menit maupun campuran WMA-2 dengan nilai deformasi sebesar 2,46 mm, stabilitas dinamis 1016,1 lintasan/mm, kecepatan deformasi 0,0413 $\mathrm{mm} /$ menit dan WMA-3 dengan nilai deformasi sebesar $2,66 \mathrm{~mm}$, stabilitas dinamis 851,4 lintasan $/ \mathrm{mm}$, kecepatan deformasi $0,0493 \mathrm{~mm} /$ menit.

\section{DAFTAR RUJUKAN}

Affandi, F., 2015. Monitoring Aplikasi Teknologi Warm Mix Asphalt, Bandung: Pusat Kajian dan Pengembangan Jalan dan Jembatan Kementerian Pekerjaan Umum.

Asphalt Institute. 2014. Asphalt Mix Design Method, Manual Series No. 2 (MS-2) 7th Edition. Lexington, USA.

Dandamanu, I. B. K., 2003. Pengaruh Kadar Aspal Dalam Campuran Beton Aspal (Spesifikasi 87) Terhadap Deformasi Permanen Dengan Menggunakan Uji "Creep" dan Hveem Stabilometer, Yogyakarta: Magister Sistem dan Teknik Transportasi, Universitas Gadjah Mada.

Direktorat Jenderal Bina Marga, 2014. Spesifikasi Umum. Dalam: Edisi 2010 Revisi (3). Jakarta: Kementerian Pekerjaan Umum.

Direktorat Jenderal Bina Marga, 2017. Manual Perkerasan Jalan: Revisi Juni 2017. Jakarta: Kementerian Pekerjaan Umum.

European Asphalt Pavement Association, 2014. The use of Warm Mix Asphalt, Belgium: European Asphalt Pavement Association (EAPA).

Gangopadhyay, S. et al., 2015. Final Report Evaluation of Zycotherm and Zydex Nanotechnologies, India: Zydex Industries.

Japan Road Association (JRA). 1980. Manual For Design and Construction of Asphalt Pavement. JRA: Tokyo.

Kusnianti, N. \& Affandi, F., 2013. Pengaruh Jenis Aspal pada Temperatur Pemadatan Berkaitan dengan Workability dari Campuran Beraspal Panas. Jurnal Jalan Jembatan, Vol. 30(No. 2), pp. 97-111. 
National Cooperative Highway Research Program, 2011. NCHRP Report 691 Mix Design Practices for Warm Mix Asphalt, Washington, D.C: Transportation Research Board of The National Academies.

Prihadi, W. R., \& Pratama, G. N. I. P. Konfigurasi Batang Pada Perancangan Rangka Atap Bambu. INERSIA, 12(2), 173-183.

PT. Jaya Trade Indonesia, 2016. https://www.slideshare.net, Diakses 2 Oktober 2017.

Sharanappanavar, M. S., 2016. Study on Behavior of Warm Mix Asphalt Using. International Journal of Science and Research (IJSR), October, 5(10), p. 5.

Sjahdanulirwan, M. \& Nono, 2010. Koefisien Kekuatan Relatif Campuran Beraspal Panas sesuai dengan Kondisi di Indonesia. Bandung, Pusat Kajian dan Pengembangan Jalan dan Jembatan Badan Kajian dan Pengembangan Kementerian Pekerjaan Umum.
Suparyanto, 2008. Pengaruh Penggunaan Aspal Pertamina AC 60/70 dan Aspal Shell AC 60/70 Terhadap Deformasi Permanen Campuran Beton Aspal (Spesifikasi Bina Marga 2007) Dikaitkan Dengan Temperatur Pemadatan Menggunakan Alat Uji Wheel Tracking Machine (WTM), Yogyakarta: Magister Sistem dan Teknik Transportasi, Universitas Gadjah Mada.

Wahyudi, M., 2000. Evaluasi Teknik Pemadatan dan Faktor-Faktor yang Berpengaruh terhadap Karakteristik Campuran Aspal Berbatuan Besar. Simposium III FSTPT Pascasarjana UGM, pp. 1-12.

Zaumanis, M., 2010. Warm Mix Asphalt Investigation, Denmark: Technical University of Denmark Departement of Civil Engineering.

Ziari, H., Mirzababaei, P. \& Babagoli, R., 2016. Properties of bituminous mixtures modified with a nanoorganosilane additive. Petroleum Science and Technology, Vol. 34(No. 4), pp. 386-393. 